\title{
"REALISTISEN" \\ VALTIOSÄÄNTÖOIKEUSTIETEEN HYVEET JA PAHEET
}

Paavo Kastari, Suomen valtiosääntö, Helsinki 1977, Lainopillisen ylioppilastiedekunnan kustannustoimikunta.

Paavo Kastari on ollut eräässä suhteessa outo ilmiö valtio-oikeutemme ja ehkä laajemminkin koko oikeustieteemme historiassa. Sen jälkeen kun Robert F. Hermansson toi 1870-luvun loppupuolella opintomatkaltaan Saksasta uunituoreina terveisinä Paul Labandin vakiinnuttamat valtio-oikeudellisen positivismin peruskonseptiot, valtio-oikeustieteemme historia on ollut lähes yksinomaisesti valtio-oikeudellisen positivismin historiaa. Esimerkiksi Saksassa Weimarin tasavallan aikana levinneet antipositivistiset ja omalla tavallaan - tahtoen tai tahtomattaan - fasismin ideologisina tienraivaajina toimineet antipositivistiset teoriat eivät meillä löytäneet otollista maaperää. Kehitys, jota valtio-oikeustieteessämme toki sentään tapahtui, rajautui aina 1960 ja 1970-lukujen vaihteeseen asti miltei kokonaan oikeuspositivistisen tradition puitteisiin.

Kastari onkin varsin selkeässä ja ohjelmallisessa antipositivismissaan ollut pitkään yksinäinen poikkeus; vasta 1960-luvun jälkipuoliskolta lähtien voidaan ehkä - tosin varauksellisesti - puhua eräänlaisesta "Kastarin koulukunnasta". Kastarin ja vallalla olleen positivistisen koulukunnan lähtökohtien jyrkkää eroavuutta osoittaa jo vastaväittäjä Kaarlo Kairan vuonna 1940 Kastarin väitöskirjaan kohdistama arvostelu. Arvostelun kärki kohdistui siihen, että Kastari oli rohjennut perinteisen tulkintajuridiikan ohella analysoida tutkimuskohteenaan olleen oikeudellisen instituution - eduskunnan hajoituskäytännön - sovellutuksia. Tämänkaltaisten "positiivisen oikeuden ulkopuolelle lankeavien" ilmiöiden tarkastelu ei Kairan käsityksen mukaan kuulunut oikeustieteellisen tutkimuksen legitiimeihin tehtäviin (Lakimies 1941, s. 450-464).

Myös uusimmassa, valtiosääntömme kokonaisesitystä tavoittelevassa teoksessaan Kastari on pysynyt uskollisena lähtökohdilleen. Hänen kunnianhimoisena pyrkimyksenään on saattaa valtiosäännön oikeusnormit ja instituutiot yhteyteen ympäristönsä, poliittisen järjestelmän kanssa. Tässä tarkoituksessa teokseen on mm. sijoitettu varsin etäällä positiivisesta valtiosääntönormistostamme liikkuva puolueita ja etujärjestöjä käsittelevä luku. Useissa yhteyksissä hän tuntuu panevan enemmän painoa tosiasiallisen valtiokäytännön esittelyyn kuin normistojen selostamiseen; teokseen sisältyy $\mathrm{mm}$. laajahko tasavallan presidentin tosiasiallisen aseman muuttumista erittelevä jakso. Pyrkimystä monipuoliseen, oikeuspositivismin ahtaat rajat ylittävään tarkastelutapaan osoittavat myös toistuvat viittaukset omaleimaisten valtiosääntöinstituutioittemme historialliseen, eritoten autonomian aikaiseen taustaan samoin kuin Kastarin suuria linjoja tavoittelevalle tyylille ominaiset kansainväliset vertailut. Vertailu ei kohdistu ainoastaan kapitalistisen maiden valtiosääntöihin ja poliittisiin järjestelmiin, vaan ylittää kapitalististen ja sosialististen maiden rajalinjankin. Sosialististen maiden tarkastelu on Kastarin omastakin mielestä siinä määrin tavatonta valtiosääntöoikeudellisessa kirjallisuudessamme, että hän on katsonut tällaisen näkökentän laajennuksen kaipaavan erityisiä perusteluja teoksen esipuheeseen.

Kastarin lähtökohdista selittyvät paljolti hänen teoksensa sekä ansiot että heikkoudet. Oikeuspositivismin juridiselle tutkimukselle asettamien ahtaiden rajojen ylittäminen on sinänsä hyväksyttävää ja tarpeellista: juridisen tutkimuksen tehtävänä ei ole niinkään "olemisen" ja "pitämisen" jyrkkä toisistaan erottaminen vaan pikemminkin niiden välisen vuorovaikutuksen osoittaminen; normistojen yhteiskunnallisen määräytyneisyyden ja yhteiskunnallisten vaikutusten historiaan ankkuroituvalla erittelyllä tulee olla oma sijansa oikeustieteellisessä tutkimuksessa.

Mutta lasta ei tule heittää pesuveden mukana: oikeuspositivismin rajoitusten ylittämisen ei saisi johtaa sen eräiden kiistattomien ansioiden unohtamiseen. Eräs näistä ansioista on erityisesti tämän päivän näkökulmasta legalismin korostaminen, missä suhteessa positivismi poikkeaa olennaisesti porvarillisista antipositivisista konseptioista. Myös Kastarin kohdalla "realistinen", tulkintaa ja käytännön sovellutuksia lain kirjaimen kustannuksella painottava ote osoittaa vaarallisuutensa. Kastarin "realismi" johtaa näet monin paikoin tosiasiallisen ja valtiosäännön normeja kovertaneen valtiokäytännön kritiikittömään hyväksymiseen. Ja tässä valtiokäytännössä on useimmiten kysymys porvarillisen demokratian keskeisten prinsiippien ja instituutioiden murenemisesta, ennen muuta eduskunnan aseman kaventumisesta.

Kastari ei ole valtiosääntöjuristina huolestunut esimerkiksi siitä, että eduskunnan budjettivalta ei mm. lisäbudjettien valtiosäännön kirjaimen vastaisen käyttämisen ja lisäbudjettimenettelyyn tulkinnallista tietä kytketyn raha-aloitteiden tekemiskiellon kautta ole nykyisellään sellainen kuin perustuslaki edellyttää. Hän ei arvostele tulkintaa, jonka mukaan perustuslain ylimmäksi valtioelimeksi asettama eduskunta on oikeutettu ryhtymään vain valtiosäännön nimen- 
omaan sallimiin toimenpiteisiin ja jonka perusteella on $\mathrm{mm}$. torjuttu toimeenpanokoneiston toimintaa selvittävien tutkimuskomissioiden mahdollisuus. Hän toteaa myös ns. lainsäädäntövallan delegointiin liittyvän eräitä käytäntöjä, jotka ovat valtiosäännön kirjaimen vastaisia: valtiosääntönormeissa ei puhuta mitään lakien täytäntöönpanomääräysten antamisoikeuden myöntämisestä ministeriöille, mutta kuitenkin "käytännössä lait ... melko usein ja enenevässä määrin uskovat täytäntöönpanomääräystensä antamisen juuri ministeriöille" (s. 285); sotatilalaki puolestaan antaa valtioneuvostolle ja sotapäällystölle pitkälle menevät valtuudet kansalaisten perusoikeuksien rajoittamiseen sodan tai kapinan aikana, vaikka "sanamuotonsa mukaan ei HM $16 \S$ (perusoikeuksien rajoittamista sodan tai kapinan aikana koskeva hallitusmuodon säännös - KT) tosin näytä oikeuttavan säätämään rajoituksia muutoin kuin 'lailla', joten delegointi asetuksen tai valtioneuvoston päätöksen portaalle asti - puhumattakaan niillä tapahtuvasta subdelegoinnista vielä alemmille säätämisportaille - ei näyttäisi tuon sanamuodon nojalla olevan luvallista" (s. 287). Mutta näissäkään tapauksissa Kastari ei katso olevan aihetta valtiosääntönormeja mittapuuna soveltavaan kritiikkiin: "vakiintunut tulkinta" ja "tavanomainen oikeus" legitimoivat valtiosäännön kirjaimen vastaisen menettelyn. Kritiikittä jäävät myös kommunistien poliittisen toiminnan ehkäisemiseksi 1930-luvulla tavallisessa lainsäätämisjärjestyksessä säädetyt paino-, yhdistymis- ja kokoontumisvapauden rajoitukset.

Kastari hyväksyy valtiosäännön näkökulmasta myös tulopoliittisen käytännön, jossa "on voitu joutua sellaisiin tilanteisiin, että perustuslain mukaisten ylimpien elinten eli siis presidentin ja eduskunnankin on ollut tyydyttävä antamaan virallisesti ainoastaan muodollinen jälkisiunauksensa tulopoliittisen ratkaisun valtiota koskevien kohtien täytäntöönpanoon esim. hyväksymällä niiden mukaisia lakiehdotuksia 'pilkkuakaan muuttamatta'." (s. 422) Miten tällainen perustuslaissa säännellyn päätöksentekomenettelyn syrjäyttävä käytäntö on sitten valtiosääntöauktoriteetin mielestä hyväksyttävissä? Sallivaksi perusteeksi näyttää osoittautuvan "yhteisen hyvän" huomioonottaminen ja yhteiskunnallamme ominaisen kiusallisen lohkoutumisen parlamentaarista demokratiaa onnistuneemmin voittavan "moniyhteisöllisen demokratian" perusajatusten toteuttaminen: "Lopputulokset (tupo-neuvottelujen - KT) perustuvat kuitenkin tyypilliseen konsensusajatteluun, jossa ratkaisua ei voida saavuttaa äänestyksellä eikä enemmistöpäätöksellä, vaan se vaatii periaatteessa kaikkien osapuolten suostumuksen. Tupo-ratkaisuissa esiintyykin pisimmälle päässeenä järjestelmämme vähittäinen ja haparoiva kehittyminen kohti ns. moniyhteisöllistä demokratiaa. Tämän näkökohdan esille tuominen käy myös vastauksesta niille tupo-menetelmän arvostelijoille, jotka väittävät etujärjestöjen riistävän perustuslainmukaisilta korkeimmilta elimiltä, eduskunnalta ja hallitukselta niille kuuluvan vallan. Tosin ei perustuslakeja näissä yhteyksissä tulkita kovinkaan jäykän legalistisesti. Mutta perimmältään ei niiden sivuuttamia valtion elimiä myöskään syrjitä eikä sivuuteta. Neuvotteluja käydään ja yhteisymmärrykseen pyritään lähinnä niiden yhteiskunnallisten voimien edustajien välillä, jotka kulloisessakin tilanteessa ovat reaalisesti painavimmat. Valtiosäännön asettamat elimet soveltavat sitten val- tuuksiaan yhteisen hyvän edellyttämällä tavalla ja lopulta muodollisestikin siunaavat saavutetun konsensuksen." (s. 423)

Ja vielä eräs esımerkki Kastarin tosiasiallisen ja yleensä porvarillisen demokratian kaventamista merkitsevän käytännön siunaavasta "realismista". Tämä esimerkki on siinäkin suhteessa merkillepantava, että se osoittaa, miten perustúslain kirjaimesta kiinnipitävä ja oikeuspositivismin ihanteista lähtevä tutkija saattaa joutua puolustamaan porvarillisen demokratian perusprinsiippejä "realistista" tutkimusotetta vastaan. Kysymys on v. 1969 tavallisessa lainsäätämisjärjestyksessä säädetystä - sittemmin lievennetystä - puolueiden ehdokasasettelumonopolista kansanedustajavaaleissa. Kastari kirjoittaa peitsensä vanhaa kiistakumppaniaan ja ehdokasasettelumonopolia perustuslainvastaisuudesta kritikoinutta Veli Merikoskea vastaan suunnaten: "Oikeudellisten muotojen kannalta tarkasteltuna riistettiin tällä uudistuksella tosin valitsijoilta välitön oikeus osallistua ehdokasasetteluun. Teoreettisiin johtopäätöksiin pelkistettynä saattoi tämän toimenpiteen kaavailla olleen siinä määrin ristiriidassa kansanvaltaisten periaatteiden kanssa, että niihin nojautumalla voitiin pystyttää tulkintarakennelmia, jotka viittasivat ristiriitaan itse perustuslainkin kanssa. Käsitykseni mukaan tätä ongelmaa eriteltäessä ja arvioitaessa on kuitenkin pantava pääpaino toisaalta ehdokasasettelu- ja toisaalta puoluejärjestelmän kokonaisuuden toiminnalle. Tästä näkökulmasta tarkasteltuna ei ristiriitaa kansanvallan enempää kuin perustuslainkaan kannalta ole ollut." (s. 381-382)

Kastarin. lähestymistavan poikkeavuus oikeuspositivismin tieteen 
ihanteista ilmenee myös hänen vastenmielisyydessään käsitteellisiä pohdintoja kohtaan: kun klassisesta saksalaisesta positivismista vaikutteita saavat oppikirjat lähtevät yleensä valtio-oikeuden peruskäsitteiden kehittelystä, valtiooikeuden tämänkaltaisella teoreettisella osalla ei ole sijaa Kastarin teoksessa. Valtion yleistä käsitettä samoin kuin valtio-oikeushenkilön, valtiovallan, valtion suvereniteetin, valtio-orgaanin jne. käsitteitä saa turhaan hakea Kastarin kirjasta.

Tämä ei ole välttämättä Kastarille eduksi esimerkiksi vertailtaessa hänen teostaan valtio-oikeuden saksalaisten klassikoiden tai heidän suomalaisten oppilaittensa tuotantoon. On tietysti niin, että klassisen positivismin käsitteenmuodostuksessa oli pahoja virheitä: "sosiaalisen" tai "luonnollisen" sekä "juridisen" jyrkkä vastakkainasettelu, käsitteiden määrätynlainen yhteiskuntatodellisuudesta irronnut itseliikunta, epähistoriallisuus jne. Mutta oikea tie "sosiaalisen" ja "juridisen" vastakkainasettelun voittamiseen ei ole luopuminen kokonaan valtion oikeudellisten aspektien käsitteellistämisestä. Myöskään esimerkiksi valtion yleisen käsitteen tai suvereniteettikäsitteen epähistoriallisuuden todellinen vaihtoehto ei ole niiden jäännöksetön relativoiminen. Valtion oikeudelliset aspektit vangitsevien käsitteiden on heijastettava "juridisen" ja "sosiaalisen" vuorovaikutusta ja käsitteiden epähistoriallisuus on voitettavissa erottamalla heijastettavissa ilmiöissä olennainen ja epäolennainen, pysyvä ja muuttuva ja sisällyttämällä kehitysaspekti itse käsitteeseen. Kenties osaksi juuri käsitteellisten välineiden kehittelyn puutteellisuudesta johtuu, että sekä valtiosääntönormien kohdealue - valtioorganisaation sisäiset sekä sen ja muun yhteiskunnan väliset (poliit- tiset) suhteet - että oikeusnormien asema näiden poliittisten suhteiden ohjaamisessa jää Kastarin teoksessa koko lailla jäsentymättömäksi, "möhkälemäiseksi", käyttääkseni Kastarin omaa suosikkitermiä. Ehkä hieman kärjistäen voitaneen sanoa, että kun Kastari on asettanut kirjalleen erääksi tehtäväksi antaa "juristeille heidän nykyisiä oppikirjojaan hiukan täyteläisempi kuva siitä ympäristöstä, jonka kanssa valtiosäännön oikeusnormit ja instituutiot ovat jatkuvassa vuorovaikutuksessa" (s. IX), lopputuloksessa on lähellä varsinaisen kohteen ympäristöönsä liudentumisen vaara.

Tämä vaara on yhteydessä teoksen ehkä perustavaan puutteeseen. Teos ei nojaudu kokonaisvaltaiseen, yhteiskunnan osa-alueiksi jäsentävään sekä näiden osa-alueiden keskinäissuhteet ja keskinäisen määräytyneisyyden osoittavaan teoriaan. Kastari operoi mielellään systeemiteorian käsitteillä ja turvautuu esimerkiksi kapitalististen ja sosialististen maiden vertailussa poliittisen ja taloudellisen järjestelmän käsitteisiin. Mutta olennaiseen kysymykseen, kysymykseen taloudellisen ja poliittisen järjestelmän keskinäisyhteydestä, hän ei anna eksplisiittistä vastausta. Ongelman pohdinta jää seuraavankaltaiselle tasolle: "Poliittinen systeemi ja talousjärjestelmä ovat siamilaisten kaksosten tapaan niin laajalti ja lujasti yhteenkasvaneet sekä olennáisessa keskinäisessä vuorovaikutuksessa että - biologista systeemivertausta jatkaakseni - edes niiden verenkiertoa saattaa olla työlästä pitää toisistaan erillään." (s. 18) Antautuminen talouden ja politiikan keskinäissuhteen ongelman edessä ei tietystikään ole pelkästään Kastarille ominaista; itse asiassa tämänkaltainen asennoituminen näyttää olevan ominaista koko "modernille", talouden ja politiikan välisen vuorovaikutuksen myöntävälle mutta samalla sen jäsentämisen mahdottomuutta korostavalle länsimaiselle valtioteorialle. Ja myös Kastarilla ainakin implisiittisesti esiintyvä pyrkimys tämän ongelman kiertämiseen etsimällä yhteiskunnan rakenteen viime kädessä määräävää tekijää talouden ja politiikan ulkopuolelta on tuttu. Kysymyksessä on pakeneminen ideologiaan: kapitalististen maiden, niiden taloudellisen ja poliittisen järjestelmän, asettaminen sosialististen maiden vastapainoksi on oikeutettua niitä yhdistävän ja sekä taloudellisessa että poliittisessa järjestelmässä ilmenevän individualistis-pluralistisen, yksilön vapaudesta lähtevän ideologian vuoksi. Ja samoin sosialistisia maita yhdistää ja niiden taloudellista ja poliittista järjestelmää selittää "uskonnonomaisella voimalla" koko yhteiskuntaa ryydittävä ideologia.

Talouden ja politiikan keskinäissuhteen ongelman kiertäminen ja ideologian asettaminen yhteiskuntakehityksen demiurgiksi tekee tietysti mahdottomaksi kapitalististen ja sosialististen maiden poliittisten järjestelmien ja valtiosääntöjen hedelmällisen vertailun. Ja kun järjestelmiä vertailtaessa vielä käytetään porvarillisen "individualistispluralistisen" ideologian silmälaseja, ei ole ihme, että sosialistisen maiden poliittisen järjestelmän tarkastelussa ajaudutaan paikka paikoin lähelle vuosikymmeniä vanhoja antikommunistisia slogaaneja. Sosialististen maiden poliittisen järjestelmän yhtenäisyyttä käsitellessään Kastari kiinnittää huomiota enemmänkin henkilöpalvonnan kauden väärinkäytöksiin kuin taloudellisesta rakenteesta johtuvan sosiaalisen rakenteen ja intressiyhtenäisyyden erittelyyn; kommunistisen puolueen roolin tarkaste- 
lussa "havainnollistavana" vertailukohteena on kirkon asema keskiajalla; marxismi-leninismiä tarkasteltaessa operoidaan enemmänkin uskonnollisilla kuin tieteellisillä termeillä jne. Kun sosialististen maiden valtiosääntöjen esittelyssä on vielä havaittavissa eräitä suoranaisia virheitä - esimerkiksi väitteet lakko-oikeuden kieltämisestä sekä juridisen velvoittavuuden puuttumisesta perustuslaissa säännellyiltä perusoikeuksilta on vaikea olla päätymättä muuhun johtopäätökseen kuin että sosialististen maiden poliittisen ja valtiosääntöisen järjestelmän käsittelyn poisjättäminen olisi sittenkin ollut onnellinen ratkaisu.

Talouden ja politiikan keskinäisyhteyden jäsentämättömyys sekä turvautuminen ideologisiin aspekteihin selitysperusteena lyö leimansa myös kapitalististen maiden valtiosäännön ja poliittisen järjestelmän tarkasteluun. Porvarillisten vapausoikeuksien syntyperusta jää aatehistorian tasolle, kapitalististen maiden poliittinen järjestelmä puolueineen ja etujärjestöineen on Kastarille paljolti vain pluralistisen ideologian eikä niinkään yhteiskunnan sosiaalisen rakenteen ilmausta, kapitalistisen valtion muuttuminen "yövartijavaltiosta" "moderniksi sosiaali-, hyvinvointitai huoltovaltioksi" näyttää joko kokonaan käsittämättömältä ilmiöltä tai selittyy vapauden ja yhdenvertaisuusprinsiippien uudelleenarvioinnista jne.

Kastari on sekä teoksessaan, että eräissä muissa julkisissa yhteyksissä ottanut kantaa myös valtiosäännön uudistamiskeskusteluun. Eräisiin hänen lähtökohtiinsa on hèlppo yhtyä. Niinpä Kastari on varmastikin oikeassa kirjoittaessaan, että "emme saa käpristyä niin hengettömään kirjanoppineisuuteen, että kuvittelisimme voita- van muutamalla pykälänpyöräytyksellä muuntaa elimellisesti kasvaneen ja kehittyneen järjestelmämme keskeisiä rakenteita uudenlaatuisiksi" (s. IX).

Mihin suuntaan ja minkälaisin perustein valtiosääntöä sitten pitäisi Kastarin mielestä tulkinnallisesti kehittää? Tässä yhteydessä joudun sivuuttamaan esimerkiksi hänen aiemminkin esittämänsä näkemykset presidentin ja valtioneuvoston ristiriitatilanteen arvioimisesta sekä tuomioistuimille tulkinnallista tietä annettavasta mahdollisuudesta lakien perustuslainmukaisuuden tarkastamiseen. Käsittelen ainoastaan hänen ajatustaan ns. moniyhteisöllisestä demokratiasta.

Merikoski on moittinut Kastaria siitä, että "Kastari ei ole koskaan ollut kiinnostunut kansanvaltaisuusperiaatteesta" (Suomen Kuvalehti 11/77). Merikoski on moitteessaan oikeassa ainakin sikäli kuin kansanvaltaisuusperiaate ymmärretään merikoskilaisittain atomisoidusta yksilöstä, äänestäjästä käsin. Kastarille yhteiskunta ei koostu äänestyslipulla varustautuneista "kansanvallan ritareista" eikä hänen ongelmanaan ole heidän heiveröisen aseensa uudelleen kunniaan nostaminen. Kastaria ei huolestuta se, että "nämä vaeltavat äänestäjät, joita jotkut ovat kutsuneet jopa 'kansanvallan ritareiksi', voivat kaikessa uljuudessaan itse asiassa... joutua taistelemaan tuulimyllyjä vastaan" (s. 390). Kastarille suomalaisen yhteiskunnan ja sen poliittisen järjestelmän keskeinen ongelma on sen syvä "lohkoutuneisuus". Poliittisen järjestelmän kehittämisen tehtävänä on puolestaan tämän lohkoutuneisuuden voittaminen, siis yhteiskunnan sisäisen integraation varmistaminen. Lohkoutuneisuuden syynä on Suomen oloissa ennen, kaikkea "erityisești vasem- miston korostama kapitalistiselle järjestelmälle ominainen luokkaluonne sekä työväenluokan omassa keskuudessa vastakohtaisuus sosialidemokraattien ja kommunistien välillä" (s. 371). Olennaiseksi ongelmaksi paljastuu siten työväenliikkeen ja erityisesti kommunistien integroiminen. Tämän ongelman ratkaisu ei Kastarin mielestä näytä mahdolliselta puoluejärjestelmän puitteissa, ei edes lainsäädännöllisiin toimenpiteisiin turvautumalla. Ratkaisu häämöttää toisaalla tulopoliittisen käytännön jo viitoittamalla korporatiivisen "moniyhteisöllisen demokratian" tiellä.

Suomen Kuvalehdelle antamassaan haastattelussa Kastari toteaakin yhteiskuntamme olevan jo "onnellisesti kehittymässä" kohti "moniyhteisöllistä demokratiaa" (SK 6/77). Enää hänen mielestään puuttuu ainoastaan sen institutionalisoiminen, jossa ei hänen mukaansa tarvittaisi perustuslain muutoksia. Tämän institutionalisoinnin mallina hän esittää Hollannin 45-jäsenisen talous- ja sosiaalineuvoston, johon ammatti- ja työväenjärjestöt valitsevat 15 jäsentä, samoin talouselämä ja loput 15 jäsentä hallitus nimittää teknokraateista, juristeista jne. Neuvoston toimenkuva samaisen haastattelun mukaan näyttäisi tällaiselta: "Neuvosto käsittelee kaikki tärkeät kysymykset ennen kuin ne viedään hallitukseen ja eduskuntaan muodollisesti päätettäviksi. Neuvostossa tehtäisiin päätökset konsensus-periaatteella, eli siten, että kaikki intressiryhmät ja ideologioiden edustajat hyväksyisivät lopullisen kompromissin. Istunnot olisivat suljettuja. Tämä mahdollistaisi sen, että asioita voitaisiin rauhassa pohtia eikä jokaista yksityiskohtaa tarvitsisi julkisuudessa jatkuvasti puolustella. Etuna olisi myös se, että jäsenet olisivat huippumiehiä eivätkä pur- 


\section{LÄNTISTÄ KESKUSTELUA SOSIOBIOLOGIASTA}

narit pääsisi mukaan." Matka parlamenttiin, siellä tapahtuvaan julkiseen keskusteluun sekä parlamentin luottamusta nauttivaan hallitukseen perustuvasta klassisesta porvarillisen demokratian mallista valtiomonopolistisen kapitalismin poliittisen järjestelmän integrointitehtävän täyttämiseen kaavailtuun "moniyhteisölliseen demokratiaan" on todella huikea.

Edellä sanottu ei tietenkään mitätöi Kastarin teoksen ansioita. Kastari esimerkiksi kiinnittää perustellusti huomiota historiallisen tradition merkitykseen eräiden valtiosääntómme erikoisuuksien muotoutumisessa, monin paikoin hyödyllistä faktatietoa tarjoavat tosiasiallisen valtiokäytännön esittelyt ja poiminnot eräiden muiden kapitalististen maiden valtiosääntöisestä järjestelmästä jne. Myös Kastarin levein vedoin maalaava tyyli pääsee tämänkaltaisessa synteesejä tavoittelevassa kokonaisesityksessä oikeuksiinsa. Ei sovi sivuuttaa myöskään sitä merkitystä, mikä kastarimaisella yhteiskunnallisten realiteettien huomioonottamista painottavalla ja oikeuspositivismin rajat ylittämään pyrkivällä tutkimusotteella saattaa olla marxilaisenkin oikeustieteellisen tutkimuksen akateemisen legitimoimisen kannalta.

Kaarlo Tuori
E. O. Wilson, Sociobiology: The New Synthesis. Cambridge, Mass., The Belknap Press of Harvard University Press, 1975.

E O. Wilsonin Sociobiology liittyy niiden kirjojen joukkoon, jotka biologi on kirjoittanut ennenmuuta biologeille, mutta jotka silti saavat laajaa huomiota myös muissa piireissä. Näistä Charles Darwinin The Origin of Species on tietysti lyömätön. Mielenkiintoon täytyy olla jokin syy Lajien Synnyn tapauksessa se ei ollut vähempää kuin vallinneen ihmiskuvan täydellinen murskaaminen. Wilsonin Sociobiology on tässä suhteessa erilainen: sekin haastaa useimmat ihmisen olemuksesta vakavassa mielessä esitetyt käsitykset, mutta tavalla, joka ei ole missään mielessä uusi. Biologille Sociobiology on silti tärkeä: siinä hahmottuu uusi tutkimusohjelma eläinten sosiaalisuuden selvittämiseksi.

Tässä kirjoituksessa haluan ensisijaisesti esittää, että Uusi Synteesi sisältää Vanhan - ja virheellisen - Analyysin ihmisen sosiaalisuudesta ja ihmisyhteiskunnan rakenteesta. Arvostelun keskittäminen murto-osaan Sociobiologyn sisällöstä (697 sivua), sen ihmistä käsittelevään lyhyehköön lukuun (28 sivua), ei ole vainoharhaisuutta: Wilsonin perimmäinen päämäärä on ihmisen liittäminen jonon jatkoksi. Lisäksi ei-biologien keskuudessa kirjasta käytävä keskustelu luonnollisesti keskittyy ihmiseen. Aluksi on kuitenkin tarpeellista lyhyesti eritellä kirjan biologista antia; lopuksi selostan kirjan herättämää angloamerikkalaista keskustelua.

\section{1.}

Sosiobiologian ongelmana ovat sosiaalista käyttäytymistä ja sosiaalisia organisaatioita muovaavat bio- logiset lainmukaisuudet. Tutkimuskohteena on koko eläinkunta, alkueläimistä ihmiseen. Wilsonin sanoin, "sosiobiologia on kaiken sosiaalisen käyttäytymisen biologisen perustan systemaattista tutkimista" (s. 4). Evoluutioteoria on keskeisin komponentti Wilsonin synteesissä. Tämän lisäksi tarvitaan tietoa populaatiobiologiasta ja eläinetologiasta; edellinen on populaatioiden geneettistä ekologiaa (tai ekologista genetiikkaa) tutkiva tieteenhaara. Sensijaan psykologia ja sosiologia jäävät Sociobiologyssa mitään merkitystä vaille, toisen luokan tieteiksi. Psykologiaa Wilsonin mukaan luonnehtii ad hoc terminologia, karkeat mallit, käyrän sovittaminen (s. 6), sosiologian syntinä on strukturalismi ja eigeneettinen luonne (s. 4).

Sociobiology on jäsennetty kolmeen osaan: (i) sosiaalisten systeemien evoluutio, (ii) mekanismit sosiaalisten organisaatioiden takana, ja (iii) systemaattinen katsaus tunnettuihin sosiaalisiin eläinlajeihin.

Ensimmäisessä luvussa Wilson puuttuu sosiobiologian filosofisiin seuraamuksiin. Huomattavasti suorasukaisemmin sanoman ydin on ilmaistu toisessa ja myöhemmässä yhteydessä (Wilson, E. O., The Central Problems of Sociobiology. In: R. May (toim.), Theoretical Ecology, Blackwell Scientific Publications, 1976.): "sosiobiologisten ongelmien ratkaisu on ehtona täysin rationaalisen moraalin luomiselle". Lyhyesti, Wilsonille ongelma on siinä että aivot, jotka enemmän tai vähemmän rationaalista moraalia luovat, ovat evoluution tulosta - evoluutio puolestaan on geenifrekvenssien muutosta, ja geenien moraali on yksinkertainen: lisääntyä toisten kustannuksella.

Wilson jatkaa relevanttien tieteenhaarojen keskinäissuhteen erit- 